TAHKIM, Jurnal Peradaban dan Hukum Islam. Vol.4 No.l (Maret, 202I) | ISSN : 2597-7962

\title{
TINJAUAN MAQASHID AL-SYARIAH TERHADAP PERILAKU BERUTANG MASYARAKAT DESA SUKAWANGI PADA MASA PANDEMI COVID-19
}

\author{
Suud Sarim Karimullah, Lilyan Eka Mahesti \\ Magister Ilmu Syariah UIN Sunan Kalijaga Yogyakata, Indonesia \\ suudsarimkarimullah@gmail.com
}

\begin{abstract}
ABSTRAK
Penelitian ini menjelaskan mengenai perilaku berutang yang ditinjauan dengan maqashid al-Syariah pada fenomena kehidupan keluarga masyarakat desa Sukawangi di masa pandemi covid-19 dengan tujuan melihat apakah perilaku berutang tersebut dapat dibenarkan dalam Islam sebab pada sejatinya hutang mempunyai sifat yang paradoks yang bisa jadi penolong atau bumerang bagi keberlangsungan hidup dalam keluarga. Penelitian lapangan (field research) adalah jenis dari penelitian ini, dengan pendekatan studi kasus (case study) melalui tinjauan maqashid al-Syariah. Sedangkan dalam pengumpulan data dilakukan dengan melalui pola observasi, wawancara dan juga akan dilakukan analisis terhadap berbagai dokumentasi, kemudian di interpretasikan secara kualitatif dengan beberapa konsep sehingga tercapai sesuatu pemahaman yang benar. Penelitian ini menghasilkan tiga kesimpulan, yaitu pertama, Perilaku berutang yang dilakukan oleh masyarakat desa Sukawangi dapat dibenarkan dan diperbolehkan dalam Islam, sebab masuk dalam kategori akad muamalah sebagai bentuk transaksi ekonomi yang terdapat nilai tolong menolong ( ${ }^{\prime}$ ' $^{\prime} w u n$ ). Kedua, Hutang membuat keharmonisan keluarga terganggu bahkan sampai berujung pada perceraian. Ketiga, terdapat beberapa keluarga di desa Sukawangi yang berhasil dan sukses dalam ekonomi dengan mengelola hutang dengan baik.
\end{abstract}

\section{Kata Kunci: Maqashid al-Syariah, Hutang, Keharmonisan, Covid-19}

\section{ABSTRACT}

This research explains the behavior of debt which is reviewed by maqashid al-Syariah on the phenomenon of family life in the Sukawangi village community during the Covid-19 of pandemic with the aim of seeing whether this indebted behavior can be justified in Islam because in fact debt has a paradoxical nature that can be a helper or boomerang for survival in the family. Field research is a type of research, with a case study approach through the maqashid al-Syariah review. Meanwhile, data collection is carried out by means of observation patterns, interviews and analysis of various documentation will be carried out, then interpreted qualitatively with several concepts so that a correct understanding is achieved. This research resulted in three conclusions, namely, first, debt behavior carried out by the people of Sukawangi village can be justified and allowed in Islam, because it is included in the muamalah contract category as a form of economic transaction where there is a value of help (ta'awun). Second, debt disturbs family harmony and even leads to divorce. Third, there are several families in Sukawangi village who are successful and successful in their economy by managing their debt well.

Keywords: Maqashid al-Syariah, Debt, Covid-19, Harmony, Covid-19 
TAHKIM, Jurnal Peradaban dan Hukum Islam. Vol.4 No.l (Maret, 202I) | ISSN : 2597-7962

\section{A. PENDAHULUAN}

Masyarakat desa Sukawangi ${ }^{1}$ merupakan salah satu masyarakat desa yang menjadi korban akibat dari pandemi Covid-19 terhadap perekonomian. Mereka untuk bisa bertahan hidup pada masa pandemi Covid-19, memutuskan untuk berutang sehingga banyak diantara mereka yang terlilit hutang diberbagai lembaga keuangan ataupun personal, mulai dari koperasi, bank plecit, rentenir, serta diberbagai bank yang lainnya. Sebelum adanya pandemi Covid-19, juga terdapat sebagian masyarakat di desa Sukawangi yang mempunyai hutang. Masyarakat desa Sukawangi berutang dengan alasan untuk kebutuhan hidup keluarga dan juga untuk menambah modal usaha pada masa pandemi Covid-19.

Perilaku berutang sudah sering dilakukan oleh masyarakat desa Sukawangi bahkan sebelum pandemi Covid-19 dan berlanjut sampai terjadinya pandemi tersebut. Akibat dari adanya pandemi Covid-19 yang sedang terjadi saat ini, maka masyarakat desa Sukawangi tidak bisa melunasi hutangnya tersebut dengan baik sesuai dengan waktu yang telah disepakati dengan pihak pemberi hutang. Dari hasil pengamatan yang ada di lapangan, selain hari libur kerja setiap harinya penagih hutang selalu mendatangi rumahrumah masyarakat desa Sukawangi meminta untuk segera melunasi hutangnya.

Berbagai potret permasalahan keluarga yang terjadi pada masyarakat desa Sukawangi akibat dari pandemi Covid-19 ini, salah satunya yang dirasakan oleh keluarga ibu N.1 (inisial). ${ }^{2}$ Sebelum adanya pandemi Covid-19, dirinya dan suami sudah mempunyai hutang kepada salah satu bank plecit dan bank syariah yang rutin memberikan dana pinjaman pada masyarakat desa Sukawangi. Mereka selalu membayar dengan lancar setiap angsuran hutang yang mereka pinjam sebab uang dari hasil hutang tersebut dijadikan untuk modal untuk berdagang. Suami dari ibu N.1 berprofesi sebagai seorang pedagang ayam keliling sedangkan ibu N.1 sendiri merupakan seorang pedagang bubur keliling. Kendati demikian, semenjak adanya pandemi Covid-19 pemasukan keuangan keluarga mereka menurun secara drastis sehingga mereka mengalami kesulitan dalam

\footnotetext{
${ }^{1}$ Desa Sukawangi sendiri terletak di Kecamatan Sukawangi, Kabupaten Bekasi, Jawa Barat yang mayoritas masyarakatnya berprofesi sebagai petani dan terdapat juga yang berprofesi sebagai pedagang keliling. Akibat dari dampak pandemi Covid-19 yang tidak hanya memberikan pengaruh negatif pada perekonomian juga memunculkan persoalan sosial pada kehidupan masyarakat desa Sukawangi.

${ }^{2}$ Ibu N.1 juga merupakan salah satu responden yang namanya penulis samarkan, untuk menjaga privasi narasumber. Wawancara dilakukan pada hari Jumat 6 November 2020, pukul 14.40 WIB.
} 
TAHKIM, Jurnal Peradaban dan Hukum Islam. Vol.4 No.l (Maret, 202I) | ISSN : 2597-7962

membayar hutang-hutangnya. Akibatnya, berdampak pada keharmonisan keluarga mereka yang tadinya dalam keadaan baik-baik saja justru saat ini dirundung masalah dan berujung pada konfik internal akibat dari hutang. Ibu N.1 juga menjelaskan bahwa dirinya dan suami sempat mempunyai keinginan untuk bercerai lantaran frustasi atas hutang yang dimiliki, sebab selalu diburu oleh penagih hutang, namun keinginan untuk bercerai tersebut ia urungkan mengingat telah memiliki dua anak yang masih kecil.

Keputusan untuk berutang pada masa pandemi Covid-19 juga dilakukan oleh Ibu N.2 (inisial). Ibu N.2 berutang untuk kebutuhan hidup keluarganya sebab ia mengaku bahwa tidak pernah memperoleh bantuan berupa sembako dari pemerintah untuk meringankan hidupnya di masa pandemi Covid-19. ${ }^{3}$ Padahal ia merupakan seorang yang berprofesi sebagai petani sedangkan suaminya memiliki profesi sebagai pedagang sayur keliling. Munculnya pandemi Covid-19 dan keadaan musim panen yang tidak menentu mengakibatkan ketidak jelasan pada pemasukan keuangan keluarga. Maka untuk mencukupi kebutuhan hidup keluarga mereka, diambilah keputusan untuk berutang kepada salah satu lembaga koperasi desa dan kepada bank harian, padahal bunga yang diberikan atas hutang tersebut cukup besar. Menurut Ibu N.2, keputusan untuk berutang yang dilakukan oleh dirinya dan suaminya untuk kebutuhan keluarga merupakan sebuah keputusan yang salah. Ia mengaku hanya dengan waktu singkat sekitar satu bulan, ia dan suaminya hanya dapat merasakan manfaat dari hutang tersebut, selebihnya ia dan suaminya dirundung masalah sebab terus-terusan ditagih oleh penagih hutang. Akibat adanya hutang tersebut, kini ia dan suaminya memutuskan untuk berpisah atau bercerai. Tidak hanya itu saja, hutang juga sangat berpengaruh dalam mendatangkan konflik kekerasan di kehidupan keluarga. Sebagaimana yang dirasakan oleh Ibu N.3 (inisial) yang mendapatkan kekerasan dari suaminya sebab adanya hutang yang dilakukannya, dan hutang tersebut ditagih kepada suaminya oleh penagih hutang. ${ }^{4}$ Kekerasan dalam rumah tangga (KDRT) yang dilakukan oleh suami kepada istrinya banyak ditemukan oleh penulis dilapangan lantaran rata-rata para istrilah yang memiliki hutang tersebut akan tetapi ditagih kepada suaminya oleh para penagih hutang.

\footnotetext{
${ }^{3}$ Ibu N.2 adalah salah satu masyarakat desa Sukawangi yang namanya penulis samarkan dengan mengunakan inisial untuk menghindari terhadap penyebaran privasi responden. Wawancara dilakukan pada hari jumat, 6 November 2020, pukul 14:50 WIB.

${ }^{4}$ Wawancara dilakukan kepada Ibu N.3, beliau merupakan warga desa yang namanya penulis samarkan untuk menghindari penyebaran privasi responden. Wawancara dilakukan pada hari jumat, 6 November 2020, pukul 10.15 WIB.
} 
TAHKIM, Jurnal Peradaban dan Hukum Islam. Vol.4 No.l (Maret, 202I) | ISSN : 2597-7962

Dari penjelasan tersebut, penulis tertarik untuk meneliti bagaimana tinjauan maqashid alSyariah terhadap perilaku berutang masyarakat desa sukawangi pada masa pandemi covid-19. Tujuan dari penelitian ini untuk melihat apakah perilaku berutang pada masa pandemi Covid-19 tersebut dapat dibenarkan dalam Islam sebab pada sejatinya hutang mempunyai sifat yang paradoks. Hal demikian, dikarenakan hutang diibaratkan sebagai sebuah pisau yang bermata dua, maka jika di manfaatkan dan dikelola dengan baik akan menjadi sebuah penolong bagi kelangsungan hidup dalam keluarga yang sedang memiliki problem ekonomi, namun disisi yang lain hutang juga bisa menjadi benalu yang dapat menyengsarakan kehidupan keluarga sebab mendatangkan konflik terhadap keberlangsungan, keharmonisan dan keutuhan serta kesejahteraan keluarga. Maka dari itu, perilaku berutang yang ada di desa Sukawangi menjadi sangat penting untuk dikaji secara mendalam dan ilmiah.

\section{B. METODE PENELITIAN}

Penelitian lapangan (field research) merupakan jenis pada penelitian ini, dengan pendekatan studi kasus (case study) melalui tinjauan maqasid al-Syariah. Sedangkan dalam pengumpulan data yang akan dilakukan melalui pola observasi, wawancara, dan juga akan dilakukan berbagai analisis terhadap segala dokumentasi yang memiliki relevansi dengan penelitian ini. Kemudian, setelah data tersebut sudah diperoleh, maka akan dilakukan interpresetasikan secara kualitatif dengan beberapa konsep dan teori ilmiah yang telah ditentukan sebelumnya sehingga dapat menghasilkan pemahaman yang dapat dibenarkan. Disamping itu, metode literature review juga akan digunakan dalam penelitian ini sebagai suatu penunjang jika data-data yang telah didapatkan diantara fenomena dan konteks tidak terlihat secara jelas. ${ }^{5}$

\section{PEMBAHASAN}

\section{Keluarga dan Perencanaan Keuangan}

a. Keluarga

Suatu lembaga sosial yang paling dasar dalam masyarakat yang mempunyai peranan strategis dalam mencetak kualitas manusia dapat diartikan sebagai keluarga. ${ }^{6}$ Keluarga $^{7}$

5 J. Vrendenbregt, Metode dan Teknik Penelitian Masyarakat, (Jakarta: Gramedia, 1987), hlm. 32. 39.

${ }^{6}$ Mufidah Ch, Psikologi Keluarga Islam Berwawasan Gender, (Malang: UIN Press, 2008), hlm. 38-

${ }^{7}$ Keluarga yang merupakan bagian dari kelompok kecil dalam kehidupan sosial masyarakat yang terbagi menjadi 2 (dua) bagian, yang antara lain; pertama, keluarga inti (nuclear family), yang merupakan bagian inti dari komponen keluarga yang terdiri dari seorang suami, istri, dan anak-anaknya. Conjugal 
TAHKIM, Jurnal Peradaban dan Hukum Islam. Vol.4 No.l (Maret, 202I) | ISSN : 2597-7962

merupakan suatu kesatuan dari unit terkecil dalam kehidupan sosial yang dimiliki oleh manusia, pengertian keluarga tersebut diberikan oleh ahli antropologi. Hal yang demikian, berdasarkan pada kenyataan bahwa keluarga merupakan satuan kekerabatan yang tinggal secara bersama dan dilandasi oleh adanya kerja sama ekonomi, dan memiliki fungsi untuk berkembang biak. ${ }^{8}$ Dalam Islam ${ }^{9}$ dikatakan bahwa keluarga adalah bentuk kesatuan yang mewujudkan hubungan relasi antara seorang laki-laki dan perempuan dengan melalui ikatan akad dalam perkawinan yang sah berdasarkan ketentuan yang sudah disyariatkan. ${ }^{10}$

Keluarga memiliki 2 (dua) fungsi dalam sosial kehidupan yang diantaranya adalah; Pertama, nuclear family atau yang dikenal sebagai keluarga inti, keluarga inti ini pada fungsinya selain berfokus terhadap kesatuan biologis juga merupakan bagian dari kehidupan sosial masyarakat dalam membentuk karakter dan perkembangannya. Maka tugas keluarga inti adalah memelihara anak dengan baik sehingga dapat membentuk insan yang memiliki pemikiran dan sikap sosial serta moral yang baik. Kedua, kewajiban keluarga yang lainnya juga harus bisa memberikan pendidikan keagamaan, keilmuan sains, dan teknologi serta pendidikan ekonomi, ${ }^{11}$ seperti mengajarkan tata cara untuk berniaga dengan baik. ${ }^{12}$

Dalam kehidupan keluarga, seorang suami memiliki kewajiban untuk selalu memenuhi segala kebutuhan yang bersifat pokok dari istri dan anak-anaknya. Namun pada kenyataannya, seorang suami terkadang belum bisa memenuhi segala sesuatu yang dibutuhkan dalam keluarganya dengan baik dan maksimal. Dalam permasalahan ekonomi

family disebut juga sebagai istilah dari keluarga inti. Kedua, keluarga besar (extended family) yang merupakan bentuk keluarga dari hubungan darah atas beberapa orang, yang terdiri dari orang tua, anak, kakek, nenek, paman, bibi dan seterusnya. Conguine family disebut juga dengan istilah keluarga besar. Lihat: Mufidah Ch, Psikologi Kelurga Islam, (Malang: UIN Malang, 2008), hlm. 40.

${ }^{8}$ Wahyu MS, Ilmu Sosial Dasar, (Surabaya: Usaha Nasional, 1986), hlm. 57.

${ }^{9}$ Islam mendorong untuk membentuk keluarga dan hidup dalam bahtera rumah tangga. Lihat: Ali Yusuf As-Subki, Fiqh Keluarga, (Jakarta: Amzah, 2010), hlm. 23.

${ }^{10}$ Aunur Rahim Faqih, Bimbingan Dan Konseling dalam Islam, (Yogyakarta: UII Press, 2001), hlm. 70.

${ }^{11}$ Faktor ekonomi adalah suatu faktor yang sangat memberikan pengaruh terhadap perilaku sosial kehidupan seseorang yang pada kenyatannya tidak dapat disangkal. Sebab fungsi dari ekonomi sendiri dapat menjadikan sebuah keluarga menjadi mandiri dengan bisa mengelola keuangan dengan cara yang baik yang disesuaikan dengan kebutuhan dan perilaku hidup. Maka dari itu, memberikan edukasi mengenai ekonomi dalam kehidupan keluarga sangatlah penting. Lihat: Jaladdin Rahmad, Islam Alternatif CeramahCeramah di Kampus, (Bandung: Mizan, 1993), hlm. 121.

${ }^{12}$ Rustina, Keluarga dalam kajian Sosiologi, MUSAWA, Vol. 6, No. 2, (Desember 2014), hlm. 287 322. 
TAHKIM, Jurnal Peradaban dan Hukum Islam. Vol.4 No.l (Maret, 202I) | ISSN : 2597-7962

tersebut, mendorong seorang istri untuk membantu suaminya dalam mencari tambahan penghasilan dengan cara meminjam uang atau berutang. Hal ini, sebagaimana dikemukakan oleh salah satu responden yang bernama Ibu N.4 (inisial) yang menjelaskan bahwa dirinya berutang untuk menambah modal usaha di koperasi Mekar, akan tetapi ia mengalami kesulitan untuk melunasi hutangnnya tersebut, disebabkan adanya pandemi Covid-19 yang mengakibatkan usahanya menjadi macet dan tidak adanya pemasukan. Kemudian ia dan suaminya memutuskan lagi untuk berutang di BTPN Syariah untuk modal membuka usaha dengan berjualan nasi uduk dan gorengan sehingga ia memiliki pemasukan dengan baik pada masa pandemi Covid-19. ${ }^{13}$

\section{b. Perencanaan Keuangan}

Tingkat kematangan spiritual dan emosional yang dimiliki oleh setiap anggota keluarga terdapat perbedaan, maka hal yang demikian juga menimbulkan perbedaan dalam problematika kehidupan keluarga. Salah satu faktor yang dapat menyebabkan runtuhnya keharmonisan dalam keluarga adalah faktor perbedaan cara pandang yang tidak sama antara setiap anggota keluarga. Perbedaan pandangan dan pemikiran mengenai agama, budaya dan ekonomi juga merupakan faktor yang mengakibatkan goyahnya keharmonisan kehidupan keluarga. Maka dari itu, dibutuhkan rasa saling menghargai antar setiap anggota agar tidak terjadi konflik dalam keluarga, apalagi dalam persoalan mengenai perencanaan ekonomi dan keuangan keluarga.

Islam telah mengatur mengenai perencanaan ekonomi dan keuangan dengan baik yang memiliki tujuan untuk mencapai kebahagiaan dunia dan akhirat tanpa harus melakukan pelanggaran terhadap ketentuan hukum yang sudah ditetapkan oleh syariat. Islam juga mengatur bagaimana untuk memperoleh pendapatan keuangan dan bagaimana cara untuk membelanjakannya dengan baik tanpa harus boros terhadap pengeluaran sehingga keuangan menjadi stabil. Maka dari itu, dibutuhkannya edukasi dan sosialisasi perencanaan ekonomi dan keuangan dalam Islam kepada masyarakat luas agar mereka dapat memahami bagaimana strategi mengatur keuangan dengan baik sehingga bisa dipraktikan dalam kehidupan dalam keluarga.

Pada tahapan pertama yang harus dilakukan dalam membuat perencanaan keuangan keluarga secara professional menurut pendapat Antony Japri yaitu; Pertama, menentukan

\footnotetext{
${ }^{13}$ Penjelasan tersebut merupakan hasil responden yang dilakukan penulis kepada Ibu N.4 pada 25 November 2020, pukul 13.50 WIB di Karang Getak, Desa Sukawangi.
} 
TAHKIM, Jurnal Peradaban dan Hukum Islam. Vol.4 No.l (Maret, 202I) | ISSN : 2597-7962

serta memastikan tujuan dalam keuangan keluarga, baik itu dari jangka pendek, menengah maupun jangka panjang. Kedua, mengetahui serta memahami kemampuan keuangan saat ini serta potensi keuangan di masa depan. Ketiga, membuat serta menetapkan laporan mengenai arus kas dan anggaran keluarga. Keempat, profil risiko harus dipahami dan dipelajari dengan baik apakah bersifat konservatif, moderat, atau agresif serta mengetahui model perencanaan keuangan yang efektif yang dapat dengan mudah untuk dipahami. ${ }^{14}$

\section{Problematika Hutang dalam Islam}

a. Problematika Hutang

Persoalan ekonomi merupakan sebuah penyebab yang kerap kali menghantui dan menganggu keharmonisan kehidupan dalam keluarga. Hal yang demikian, disebakan oleh tingkat terhadap kebutuhan yang tinggi tanpa terkontrol ketika menjalani kehidupan sosial sehingga tidak bisa mengatur keadaan ekonomi dengan baik. Jikalau pengelolaan dengan cara yang tidak baik terhadap keuangan dalam kehidupan keluarga, maka akan berpengaruh negatif terhadap kebutuhan finansial keluarga dengan tidak akan terpenuhinya segala kebutuhan hidup keluarga dan juga akan mengalami penghambatan yang mengakibatkan pada munculnya beberapa faktor lain, seperti adanya tekanan spiritual, emosional, mental dan sosial serta yang lainnya. Maka dari itu, untuk tetap bisa menghindari berbagai faktor negatif tersebut, maka harus bisa memenuhi kebutuhan keuangan keluarga meskipun cara yang dilakukan adalah dengan berutang untuk mendapatkan modal dengan tujuan memperbaiki ekonomi dalam keluarga. ${ }^{15}$

Berutang dalam pandangan Islam dapat dibenarkan sebab merupakan suatu bentuk perbuatan ekonomi yang berlandaskan atas saling tolong menolong sesama manusia antara peminjam hutang dengan pihak yang memberikan hutang. Istilah qardh yang merupakan penyebutan hutang dalam Islam memiliki definisi bahwa qardh adalah upaya memberikan pinjaman kepada orang lain dengan syarat pihak yang meminjam harus mengembalikannya kembali sesuai dengan waktu yang disepakati antara kedua belah pihak. ${ }^{16}$ Hutang secara etimologi, berkonotasi terhadap uang atau barang yang

\footnotetext{
${ }^{14}$ Antony, Japri, Konsep Perencanaan Keuangan Keuangan Keluarga, Dokumen Internal Financial Planner Assosiasi Indonesia, 23 Agustus 2012.

15 Syaparuddin, Pengelolaan Keuangan Keluarga Secara Profesional dalam Menwujudkan Keluarga Sakinah, Al-Risalah: Jurnal Hukum Keluarga Islam, Vol. 1, No. 1, (Juli 2014), hlm. 76-91.

${ }^{16}$ Ismail Nawawi, Fiqh Muamalah Klasih dan Kontemporer Hukum Perjanjian Ekonomi dan Bisnis dan Sosial, (Surabaya: Ghalia Indonesia, 2012), hlm. 177.
} 
TAHKIM, Jurnal Peradaban dan Hukum Islam. Vol.4 No.l (Maret, 2021) | ISSN : 2597-7962

dipinjamkan dan mempunyai kewajiban untuk membayar kembali atau mengembalikan atas apa yang sudah diterima dengan sesuatu yang sama jumlahnya. Sedangkan menurut terminologi, hutang merupakan suatu pemberian harta terhadap orang lain untuk diambil manfaatnya setelah itu dikembalikan kembali kepada pemberi hutang sebagai ganti atas apa yang diberikan. ${ }^{17}$ Mayoritas ahli fikih mengatakan bahwa segala sesuatu yang bisa dijual belikan secara sah berdasarkan syariat, maka sah pula untuk dihutangkan. Baik itu berupa uang atau barang-barang yang dapat ditakar. ${ }^{18}$

b. Dasar Hukum dalam Hutang-Piutang

Adapun dasar dalam Islam mengenai hutang-piutang dapat ditemukan dalam Al-Quran pada surah al-Maidah ayat $2^{19}$ dan surah al-Hadid ayat $11^{20}$ serta disebutkan juga mengenai hutang-piutang dibeberapa hadis Nabi Muhammad Saw yang berbunyi:

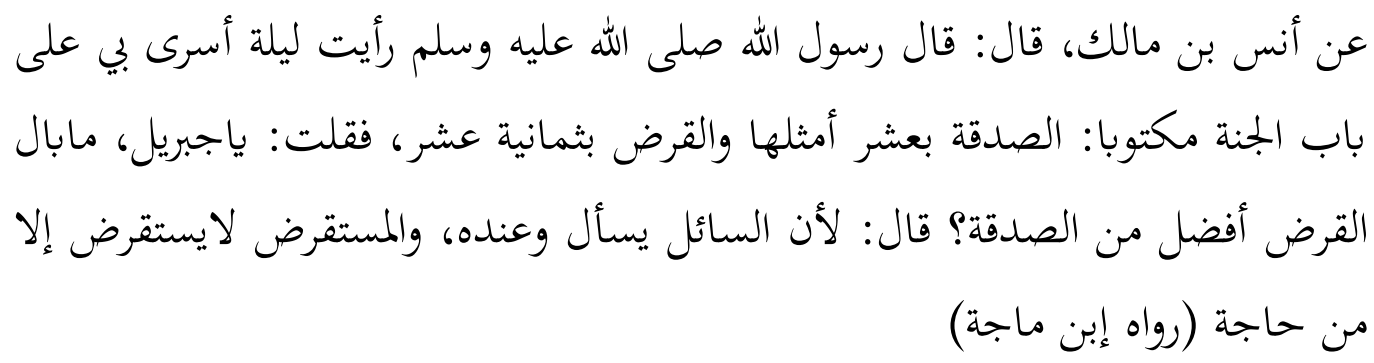

Artinya:

Dari Anas Ibn Malik Ra berkata, Rasulullah Saw bersabda: "Pada malam aku di isra'kan aku melihat pada sebuah pintu surga yang tertulis shadaqah dibalas sepuluh kali lipat

${ }^{17}$ Syaikh Shaleh Bin Fauzan al-Fauzan, Mulkhas Fiqih PanduangFiqih Lengkap Jilid 2, (Jakarta: Pustaka Ibnu Kasir, 2013), hlm. 99.

${ }^{18}$ Abu Sura'i Abdul Hadi, Bunga Bank Dalam Islam, (Surabaya: al-Ikhlas, 1993), 127.

${ }^{19}$ (QS. al-Maidah ayat [5]: 2)

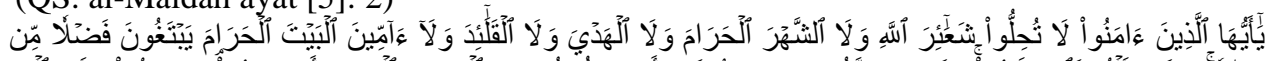

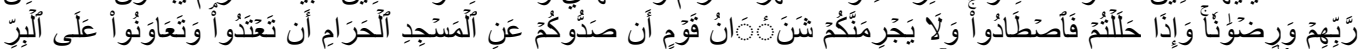

Artinya:

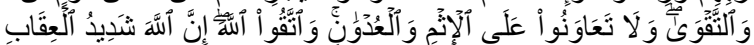

"Hai orang-orang yang beriman, janganlah kamu melanggar syi'ar-syi'ar Allah, dan jangan melanggar kehormatan bulan-bulan haram, jangan pernah (mengganggu) binatang-binatang had-ya, dan binatang-binatang qalaa-id, dan jangan (pula) kamu mengganggu orang-orang yang mengunjungi Baitullah sedang mereka mencari kurnia dan keridhaan dari Tuhannya dan apabila kamu telah menyelesaikan ibadah haji, maka bolehlah berburu. Dan janganlah sekali-kali kebencian(mu) kepada sesuatu kaum karena mereka menghalang-halangi kamu dari Masjidilharam, mendorongmu berbuat aniaya (kepada mereka). Dan tolong-menolonglah kamu dalam (mengerjakan) kebajikan dan takwa, dan jangan tolong-menolong dalam berbuat dosa dan pelanggaran. Dan bertakwalah kamu kepada Allah, sesungguhnya Allah amat berat siksa-Nya”.

${ }^{20}$ (QS. Al-Hadd [57]: 11)

Artinya:

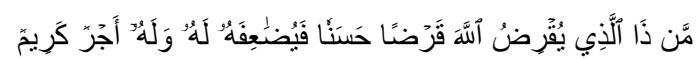

"Siapakah yang mau meminjamkan kepada Allah pinjaman yang baik, maka Allah akan melipatgandakan dengan balasan pinjaman itu untuknya, dan dia akan memperoleh pahala yang sangat banyak”. 
TAHKIM, Jurnal Peradaban dan Hukum Islam. Vol.4 No.l (Maret, 2021) | ISSN : 2597-7962

dan hutang dibalas delapan belas kali lipat”, lalu aku bertanya: "Wahai Jiblil, mengapa mengutangi lebih utama daripada sedakah? Ia menjawab: "karena meskipun seorang pengemis meminta-minta namun masih mempunyai harta, sedangkan seorang yang berutang pastilah karena ia membutuhkannya. (HR. Ibnu Majah). ${ }^{21}$

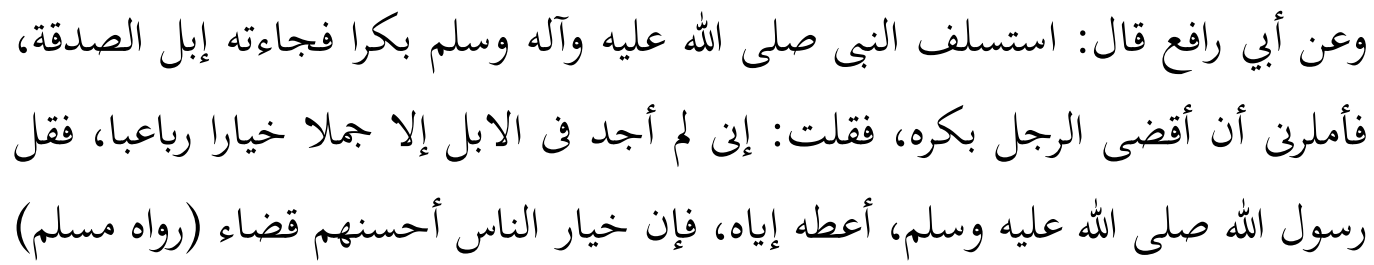

Artinya:

"Seorang Lelaki memberikan hutang seekor unta kepada Nabi Saw. Maka beberapa saat kemudian ia mendatangi nabi untuk menagih kembali untanya. Nabi Saw berkata: berikanlah kepadanya. Para sahabat mencari seekor unta yang seumuran yang dipinjam Nabi, namun para sahabat tidak menemukan unta seumuran kecuali unta yang lebi tua. Nabi Saw berkata: Berikanlah unta yang lebih tua itu. Orang itu berkata: Anda telah membayar penuh kepadaku, mudah-mudahan anda dibayar penuh oleh Allah. Mendengar itu, Nabi pun bersabda: Sesungguhnya orang yang paling baik diantara kamu adalah orang yang paling baik pembayarannya" (HR. Muslim). ${ }^{22}$

c. Rukun dan Syarat Hutang-Piutang

Rukun dan syarat ${ }^{23}$ hutang-piutang (qardh) yang harus dipenuhi, antara lain:

1) Pihak yang meminjam (muqtarik) ${ }^{24}$ adalah orang yang sudah cakap hukum.

${ }^{21}$ Ibnu Majah, Sunan Ibnu Majah, Juz II, (Beirut: Dar al-Fikr), hlm. 15.

${ }^{22}$ Ahmad Ibnu Ali Syafi'i, Buluqhul Marom, (Jakarta: Dar al-Kutub al-Islamiyah, 2002), hlm. 158.

${ }^{23}$ Mengenai syarat pinjaman harus memenuhi kriteria sebagai berikut; pertama, jumlah pinjaman harus bisa diketahui secara jelas baik melalui timbangan atau alat takar yang lain. Kedua, harus diketahui sifat pinjamannya secara jelas dan batas waktu pengembaliannya. Ada beberapa hal yang dijadikan penekanan dalam berutang, yaitu mengenai nilai sopan satun terkait berutang, antara lain:

1) Adanya bukti dari proses hutang-piutang, maka dari itu proses tersebut harus ditulis dan terdapat juga sanksi dalam proses tersebut.

2) Berutang atau memintam hendaknya dilakukan atas dasar kebutuhan yang sangat mendesak

3) Pihak yang memberikan hutang hendaknya mempunyai niat baik yang tertanam dalam hati untuk membantu pihak yang berutang.

4) Mensegerakan membayar hutang bagi orang yang mempunyai hutang tersebut. Lihat: Hendi Suhendi, Fiqh Muamalah, (Jakarta: Rajawali Press, 2014), hlm. 98.

${ }^{24}$ Pihak yang meminjam (muqtarik) harus merupakan ahliyah mu'amalah, yaitu bailgh, berakal, dan tidak mahjur 'alaih (orang yang tidak diperbolehkan oleh syariay untuk mengatur hartanya sendiri). Lihat: Dumairi Nor, Sufandi, dkk, Ekonomi Syariah Versi Salaf, (Pasuruan: Pustaka Sidogiri, 2007), hlm. 103. 
TAHKIM, Jurnal Peradaban dan Hukum Islam. Vol.4 No.l (Maret, 202l) | ISSN : 2597-7962

2) Pihak yang memberikan pinjaman (muqrid) ${ }^{25}$ harus berdasarkan kehendak sendiri dan tanpa ada paksaan dari siapapun.

3) Barang atau benda yang dihutangkan (muqtarad/ma'qud 'alaih) merupakan sesuatu yang memiliki nilai atau berharga.

4) Sighah Aqad yang dilakukan dengan melalui ijab dan qabul diantara masingmasing pihak dengan cara yang jelas sesuai dengan ketentuan qardh.

Hukum dalam akad hutang-piutang ( $q a r d h$ ) yang harus dipenuhi dan diperhatikan dalam transaksi antara pihak peminjam (muqtarik) dan pemberi pinjaman (mukrid) antara lain: ${ }^{26}$

1) Objek akad yaitu harta benda yang memiliki nilai dan harus mal mutaqawwimin meskipun dalam hal ini, terdapat perbedaan diantara para ulama fikih.

2) Tujuannya yaitu 'iwad atau countervalue berupa pinjaman tanpa riba (tambahan)

3) Shighah (ijab dan qabul).

\section{Problematika Keluarga Desa Sukawangi Pada Masa Pandemi Covid-19}

Tingkat perekonomian keluarga desa Sukawangi masih tergolong rendah. Minimnya tingkat pendidikan yang dimiliki dan kurangnya penyuluhan menjadi salah satu faktor penyebabnya. Masyarakat desa Sukawangi hidup dengan penuh kesederhanaan pada hari-hari biasa, namun ketika terjadi pandemi Covid-19 yang terjadi pada saat ini, sangatlah memberikan dampak negatif dalam kehidupan mereka yang penuh dengan kekurangan sehingga kehidupan mereka menjadi sangat memprihatinkan.

Bantuan dari pemerintah yang menjadi harapan bagi mereka yang sejak awal ditargetkan pada kalangan masyarakat kecil yang membutuhkan seperti masyarakat desa Sukawangi pun tidak seluruhnya mereka dapatkan. Bantuan dari pemerintah yang seharusnya mereka dapatkan malah tidak tepat sasaran dan pembagianya tidak merata pada saat pandemi Covid-19 sehingga menjadi sebuah problem sosial terhadap kelangsungan dalam bertahan hidup. Menurut penjelasan dari Ibu N.5 (inisial) yang merupakan salah satu

${ }^{25}$ Beberapa syarat yang harus dipenuhi oleh pihak yang memberikan pinjaman ( muqrid), antara lain: (1) Ahliyat at-Tabarru' (layak sosial), maksudnya orang yang mempunyai hak penuh dan cakap dalam menggunakan hartanya secara mutlak. (2) iktiyar (tanpa paksaan), dalam memberikan pinjaman kepada orang lain harus berdasarkan keinginan dan kehendak sendiri tanpa ada paksaan dan tekanan dari pihak manapun. Lihat: Dumairi Nor, Sufandi, dkk, Ekonomi Syariah Versi Salaf, (Pasuruan: Pustaka Sidogiri, 2007), hlm. 102.

${ }^{26}$ Ascarya, Akad dan Prodok Bank Syariah, (Jakrta: Jarawali Press, 2012), hlm. 48. 
TAHKIM, Jurnal Peradaban dan Hukum Islam. Vol.4 No.l (Maret, 2021) | ISSN : 2597-7962

masyarakat desa Sukawangi yang memiliki profesi sebagai buruh petani mengatakan bahwa dirinya selama masa pandemi Covid-19 hanya mendapatkan bantuan sembako satu kali. Ia juga membandingkan dengan tetangganya yang sering mendapatkan bantuan dari pemerintah secara berkala sedangkan tetangganya tersebut memliki sawah sendiri. ${ }^{27}$ Bantuan dari pemerintah yang tidak tepat sasaran tidak hanya dialami oleh Ibu N.5 akan tetapi penulis juga mendapati 10 orang warga masyarakat desa Sukawangi yang mengeluhkan hal yang sama ketika dilakukan wawancara.

Problematika kehidupan masyarakat desa Sukawangi pada masa pandemi Covid-19 terdapat pada faktor ekonomi yang menjadi persoalan yang urgen dalam kehidupan keluarga sehingga menjadikan banyak keluarga di desa tersebut tergiur dan memutuskan untuk meminjam uang di bermacam tempat untuk memenuhi kebutuhan hidup dan juga modal usaha. Di desa Sukawangi sendiri, terdapat beberapa jasa peminjaman uang baik untuk konsumsi maupun untuk usaha. Jasa pinjaman tersebut, antara lain; Pertama, PT Mekar Investama Sampoerna yang merupakan sebuah perseroan terbatas yang memberikan jasa simpan pinjam, dan didirikan untuk meningkatkan kualitas bagi para UMKM di Indonesia. Kedua, Bank Tabungan Pensiunan Nasional (BTPN) Syariah yang merupakan salah satu bank swasta yang bergerak dibawah naungan dan pantauan OJK dan BI (Bank Indonesia). Meskipun BTPN Syariah menetapkan sistem dengan prinsip syariah akan tetapi pada penetapan marginnya masih cukup besar yaitu sebesar $30 \%$. Ketiga, MBK (Mitra Bisnis Keluarga) yang cara kerjanya mirip dengan lembaga peminjaman dana lainnya. Keempat, Bank harian. Selain itu, juga terdapat Bank Plecit yang memiliki karakteristik yang sama dengan rentenir. Bank plecit merupakan lembaga atau perorangan yang menawarkan pinjaman dalam jangka pendek tanpa jaminan akan tetapi mempunyai tingkat bunga yang relatif tinggi. ${ }^{28}$

Penulis menemukan bahwa mayoritas keluarga di desa Sukawangi memiliki pinjaman hutang pada satu lembaga peminjam hutang bahkan terdapat banyak juga keluarga yang meminjam hutang dilebih dari satu lembaga pemberi hutang. Sesuai dengan pengamatan yang dilakukan oleh penulis yang diperoleh langsung dilapangan dengan melalui sistem wawancara kepada 30 keluarga yang mencakup 5 tokoh masyarakat disana, maka

\footnotetext{
${ }^{27}$ Hasil wawancara yang dilakukan penulis kepada Ibi N.5 pada 25 November 2020, pukul 13:25 WIB di Karang Getak, Desa Sukawangi.

${ }^{28}$ Heru Nugroho, Uang, Retenir dan Hutang di Jawa, (Yogyakarta: Pustaka Pelajar, 2001), hlm. 80.
} 
TAHKIM, Jurnal Peradaban dan Hukum Islam. Vol.4 No.l (Maret, 202I) | ISSN : 2597-7962

ditemukan bahwa problematika keluarga di desa tersebut disebabkan oleh alasan yang hampir sama, yaitu masalah ekonomi. Untuk membenahi perekonomian keluarga, kebanyakan dari mereka memutuskan untuk berutang demi bisa merintis usaha atau meneruskan usaha selama masa pandemi Covid-19.

Penulis melakukan wawancara yang bersifat semi terstruktur dengan menggunakan daftar pertanyaan yang dikembangkan berdasarkan literatur terkait kepada 30 keluarga yang ada di desa Sukawangi. 30 keluarga yang menjadi responden tersebut merupakan keluarga yang memiliki hutang hingga saat terjadi pandemi Covid-19 seperti saat ini. Para responden yang berhasil dimintai keterangan oleh penulis keseluruhan merupakan perempuan, sebab sebagian besar laki-laki atau suami di desa Sukawangi merupakan seseorang yang berprofesi sebagai petani dan pedagang keliling, jadi sangat sulit bagi penulis untuk bertemu dengan mereka dalam meminta keterangan karena tidak ada dirumah ketika pagi sampai sore.

Berdasarkan dari hasil wawancara yang telah dilakukan penulis terhadap 30 responden. Penulis menemukan bahwa terdapat 9 kasus perceraian yang dialami oleh responden. Responden yang diwawancarai ini mengaku bahwa sebagian besar penyebab pertengkaran dan perceraian dalam rumah tangga mereka disebabkan oleh persoalan ekonomi keluarga. Persoalan yang begitu kompleks dari perekonomian keluarga disebabkan adanya hutang yang terus membayangi kehidupan keluarga dan menjadi sebuah problem yang sangat serius pada masa pandemi Covid-19, lantaran minimnya pemasukan sehingga membuat mereka kesulitan untuk membayar hutang-hutangnya.

Terdapat sembilan keluarga dari tiga puluh responden yang memutuskan untuk bercerai akibat dari persoalan ekonomi keluarga karena hutang. Jika di persentasikan mengenai jumlah responden yang memutuskan untuk bercerai, maka terdapat 30\% jumlahnya. Meskipun ada satu keluarga dari sembilan keluarga yang memilih bercerai memang tidak berutang pada masa pandemi Covid-19 akan sisa hutangnya masih ada pada masa pandemi Covid-19.

Selain itu, terdapat juga 15 responden yang mengalami konflik dalam keluarganya yang diakibatkan oleh hutang. Salah satu hasil pengakuan dari responden yang sering mengalami konflik dalam kehidupan keluargannya menjelaskan bahwa hutang telah membuat keluarganya tidak harmonis lagi dan sering mendatangkan konflik. Jika 
TAHKIM, Jurnal Peradaban dan Hukum Islam. Vol.4 No.l (Maret, 202I) | ISSN : 2597-7962

terdapat 15 responden yang sering mengalami konflik dalam keluarganya, maka hasil persentasenya adalah $50 \%$.

Tidak hanya itu, terdapat sebanyak 12 perempuan telah menjadi korban kekerasan dalam rumah tangga (KDRT) yang berdampak buruk pada fisik, psikis maupun batinnya. KDRT terjadi disebabkan oleh hutang yang dilakukan istri sehingga suaminya merasa selalu terbebani dan terusik sebab setiap harinya sang istri selalu meminta uang untuk melunasi hutangnya tersebut. Namun demikian, terdapat juga istri yang merasa dibebani oleh suaminya akibat dari hutang yang dilakukan oleh suaminya tersebut. Kemudian, penulis juga mendapati banyak sekali keluarga yang sering bertengkar atau cek-cok mengenai permasalahan ekonomi dan hutang dalam keluarga. Keluarga yang jarang mengalami konflik lantaran hutang sebanyak 3 keluarga atau sebesar 10\%. selanjutnya, keluarga yang sangat minim sekali terjadinya konflik dalam rumah tangga sebab persoalan hutang adalah sebanyak 3 keluarga dengan persentase $10 \%$.

Pada ketiga keluarga yang jarang sekali terjadi konflik dan tiga keluarga yang minim akan adanya konflik, pada kenyataanya mereka juga mempunyai hutang sebelum atau saat terjadinya pandemi Covid-19. Namun, 6 keluarga tersebut tidak mempunyai problem pada aspek ekonomi ataupun kesulitan terhadap finansial keluarga yang serius maupun kesulitan dalam membayar hutang akibat pandemi Covid-19. Justru terdapat 2 keluarga yang memutuskan untuk berutang pada masa pandemi Covid-19, padahal sebelumnya mereka tidak mempunyai hutang sebelum terjadi pandemi. Mereka sangat pandai dalam melihat peluang dan memanfaatkan hutang yang mereka pinjam dengan dijadikan tambahan modal usaha pada masa pandemi Covid-19. Hasil dari hutang yang mereka pinjam dijadikan sebagai modal usaha air minum dalam galon dan usaha ikan hias.

Faktor ekonomi yang menjadikan masyarakat desa Sukawangi memberanikan diri untuk berutang demi kebutuhan hidup keluarga dan untuk tambahan modal usahanya. Hutang yang dipinjam oleh masyarakat Sukawangi berdampak buruh terhadap ketengan hidup dan keharmonisan keluarga. Hal ini disebabkan oleh adanya penagih hutang yang setiap hari mendatangi rumah-rumah masyarakat untuk menagih hutang yang telah mereka pinjam. Sebab dari itu, terdapat beberapa keluarga di desa Sukawangi yang mengalami konflik yang berujung pada perceraian. 
TAHKIM, Jurnal Peradaban dan Hukum Islam. Vol.4 No.l (Maret, 202I) | ISSN : 2597-7962

Menurut pengakuan dari Ibu N.6 (inisial) yang merupakan mantan istri dari bapak RR (inisial) yang merupakan warga desa Sukawangi. ${ }^{29}$ Ia menjelaskan bahwa dirinya memiliki hutang di MBK (Mitra Bisnis Kelurga). Ia berani berutang karena ingin manambah modal usahanya yang ia dilakukan bersama suaminya. Usaha yang ia lakukan adalah dengan berjualan ikan segar keliling bersama suaminya. Ia meminjam dana usaha sebelum terjadinya pandemi Covid-19 dan setoran pembayaran hutang setiap minggunya tidak pernah mengalami kendala dan selalu full dalam membayarkan setoran hutang perminggunya. Namun ketika terjadinya pandemi Covid-19 pendapatan usahanya benarbenar menurun, bahkan pernah di suatu hari dagangannya tidak ada satu orang pun yang membeli. Akibat dari pandemi Covid-19, maka ia dan suaminya mengalami kesulitan dalam membayar hutangnya disebabkan tidak ada pemasukan keuangan yang dimiliki. Kemudian, terjadilah konflik dalam keluarga yang dimulai dengan perilaku suaminya yang kesal lantaran sering dimintakan uang untuk setoran pembayaran hutang. Sejak saat itu keluarganya tidak lagi harmonis dan saat ini ia dan suaminya telah resmi bercerai secara agama namun belum secara hukum negara karena kasus perceraiannya belum di selesaikan secara hukum di pengadilan.

Selain itu, terdapat juga Ibu N.7 (inisial) yang mengalami KDRT dari laki-laki yang saat ini masih menjadi suaminya. ${ }^{30}$ Ia merupakan seorang Ibu rumah tangga yang memiliki sebuah usaha kecil, yaitu warung jajanan anak-anak dan terletak di pinggir jalan depan rumahnya. Suaminya adalah bapak M (inisial) yang berprofesi sebagai penjual siomay keliling. Ia merupakan orang yang menerima pinjaman usaha dari BTPN (Bank Tabungan Pensiunan Nasional) Syariah. Namun Usaha mengalami penurunan pada sama pandemi Covid-19. Sementara setoran pembayaran hutangnya yang dilakukan setiap dua minggu sekali tersebut tidak mengalami gangguan. Kemudian, pada saat pandemi Covid19 ia memutuskan untuk meminjam dana kepada bank 'plecit' untuk kebutuhan dan tambahan modal usahanya. Semenjak saat itulah, kehidupan keluarganya menjadi tidak harmonis lagi. Suaminya sering kali kesal dan mengamuk hingga membanting perabotan rumah tangga saat dimintakan uang untuk membayar hutang kepada bank plecit tersebut. Meskipun demikian, ia dan suaminya tidak sampai mengakhiri perkawinan dengan cara

\footnotetext{
${ }^{29}$ Merupak sebuah penjelasan tersebut merupakan hasil wawancara yang dilakukan penulis kepada Ibu N.6 pada 25 November 2020, pukul 13.20 WIB di Karang Getak, desa Sukawangi.

${ }_{30}$ Pemaparan tersebut merupakan data wawancara yang dilakukan penulis terhadap Ibu N.7 di Karang Getak, desa Sukawangi pada 26 November 2020 pada pukul 15.30 WIB.
} 
TAHKIM, Jurnal Peradaban dan Hukum Islam. Vol.4 No.l (Maret, 202I) | ISSN : 2597-7962

bercerai sebab ia mendapatkan pijaman lagi dari Bank syariah yang memberikan keringanan sebesar setengah angsuran setiap 2 minggu sekali.

Segala penjelasan yang sudah dijelaskan oleh penulis di atas merupakan beberapa problematika kehidupan rumah tangga yang dialami oleh masyarakat di desa Sukawangi. Kasus kekerasan dalam rumah tangga (KDRT) yang menjadikan terganggunya keharmonisan dalam keluarga di desa tersebut rata-rata terjadi lantaran adanya hutang yang melilit kehidupan keluarga di desa Sukawangi bahkan sampai ada yang berujung dengan perceraian. Selain kedua Ibu tersebut, penulis juga mendapati sekitar 40 kasus perceraian, KDRT, dan menurunnya kualitas harmonis dalam kehidupan keluarga di desa Sukawangi, Jawa Barat.

\section{Tinjauan Maqashid al-Syariah Terhadap Perilaku Berutang Masyarakat}

\section{Desa Sukawangi}

Secara garis besar, para ulama menjelaskan bahwa tujuan dari syariah adalah menjaga eksistensi keharmonisan dan kesejahteraan hidup manusia, yang terfokus pada lima aspek, yaitu memelihara agama (hifzhud din), memelihara jiwa (hifzhun nafs) memelihara akal (hifzhul 'aql), memelihara keturunan (hifzhun nasl), dan memelihara harta (hifzhul maal). ${ }^{31}$ Pada maqashid al-Syariah terdapat nilai subtansi kemaslahatan untuk kehidupan manusia.

Dalam memenuhi kebutuhan hidup yang bersifat primer (dharuriyah) harus bisa melihat manfaatnya dan kemaslahatannya, apabila dalam keadaan darurat maka diperbolehkan. Berbeda dengan kebutuhan sekunder (hajjiyah) yang apabila tidak terpenuhi tidak akan mengancam terhadap keselamatan hidup pada diri seseorang, meskipun kebutuhan sekunder (hajjiyat) juga dibutuhkan untuk menunjang agar mempermudah terhadap segala aktifitas yang dilakukan oleh seseorang. Sebab kebutuhan ini untuk membantu dalam memaksimalkan kebutuhan sehingga bisa meminimalisir kesulitan, kesusahan dan kesempitan agar hasilnya bisa maksimal. Setelah itu, mengenai kebutuhan tersier (tahsiniyat) atau juga sebagai pelengkap (kamaliyat) merupakan tingkat kebutuhan yang apabila tidak terpenuhi tidak akan mengancam pada eksistensi salah satu dari kelima pokok tujuan dari maqashid al-Syariah diatas dan tidak pula menimbukan kesulitan untuk manusia karena hanya sebagai pelengkap.

\footnotetext{
${ }^{31}$ Fathurrahman Djamil, Filsafat Hukum Islam, (Ciputat: Logos Wacana Ilmu, 1997), hlm. 126
} 
TAHKIM, Jurnal Peradaban dan Hukum Islam. Vol.4 No.l (Maret, 202I) | ISSN : 2597-7962

Prinsip falah yang dikenal dalam Islam digunakan sebagai prinsip dasar dan pertimbangan dalam ekonomi yang bertujuan agar segala keputusan yang diambil dalam segala kegiatan perekonomian haruslah seimbang (tawazun) dan tidak boleh berlebilebihan (al-israf) serta mempertimbangkan kebahagiaan dunia dan akhirat. Sebagaimana dijelaskan bahwa setiap kegiatan maupun keputusan yang menyangkut perekonomian haruslah balance antara manfaat dunia dan akhirat. Dalam Islam perilaku berutang dapat dibenarkan dan diperbolehkan sebab masuk dalam kategori akad muamalah sebagai bentuk transaksi ekonomi yang terdapat nilai tolong menolong (ta'awun). Islam mempertimbangkan segala bentuk baik dan buruknya serta manfaat dan tidaknya. Begitupun dengan hutang yang harus bisa dengan benar disaring manfaat dan mudharatnya. Kemudian apa yang akan terjadi, seseorang yang berani berutang maka harus siap untuk mengembalikan apa yang telah dihutanginnya sesuai dengan kesepatakan yang telah ditentukan.

Sesuai dengan hasil pengamatan dilapangan yang dilakukan oleh penulis, maka ditemukan bahwa persoalan masyarakat desa Sukawangi yang menyebabkan retaknya keharmonisan dalam kehidupan keluarga disebabkan oleh hutang yang mereka pinjam. Mereka berani untuk berutang selain betujuan untuk kebutuhan hidupnya, juga sebagai tambahan modal untuk usahanya. Jika dilihat dari segi prinsip dalam Islam, maka perilaku yang demikian tersebut dapat dibenarkan dan diperbolehkan. Perhitungan dan penggunaan dana hutang yang kurang tepat dan tidak akurat justru akan menjadikan hutang tersebut menjadi bumerang bagi kehidupan rumah tanga.

Berutang demi memperoleh dana untuk usaha yang dilakukan oleh seseorang yang kurang paham dalam mengelola keuangan, maka hal yang demikian juga dapat menjadi banalu yang melahirkan konflik dalam keharmonisan rumah tangga. Sedangkan untuk seseorang yang memiliki perhitungan yang akurat dan paham terhadap pengelolaan keuangan dengan baik, maka ia dapat mengelola dana hutang dengan tepat dan akurat sehingga hutang tersebut tidak menjadi sebuah problem bagi hidupnya akan tetapi hutang tersebut akan penyelamat terhadap kelangsungan hidup dirinya dan keluarganya di tengah pandemi Covid-19 yang terjadi saat ini. Hal yang demikian, sudah dirasakan oleh keluarga Ibu N.4 (inisial) dan Ibu N.6 (inisial) yang memanfaatkan dana hasil hutang 
dengan mengelolanya dengan baik dan membuka peluang usaha sehingga keluarga mereka sangat minim konflik yang diakibatkan oleh problem finansial keluarga. ${ }^{32}$

Perilaku berutang yang dilakukan oleh masyarakat desa Sukawangi meskipun di perbolehkan oleh Islam akan tetapi mereka banyak yang belum bisa dan gagal dalam mengelola dana hasil hutang tersebut sehingga berdampak negatif terhadap kehidupannya terlebih kepada keharmonisan keluarganya. Meskipun demikian terdapat juga masyarakat desa Sukawangi yang beruntung dengan berutang sebab ia mampu mengelola dengan baik hasil hutang tersebut dengan membuka peluang usaha pada masa pandemi Covid-19.

\section{SIMPULAN}

Masyarakat desa Sukawangi mempunyai ketergantungan ekonomi dengan mengandalkan hutang pada masa pandemi Covid-19 untuk bisa bertahan hidup dan tambahan modal usaha. Perilaku berutang yang dilakukan oleh masyarakat desa Sukawangi dapat dibenarkan dan diperbolehkan dalam Islam, sebab masuk dalam kategori akad muamalah sebagai bentuk transaksi ekonomi yang terdapat nilai tolong menolong (ta'awun). Terdapat banyak keluarga di desa Sukawangi yang terlilit hutang dan mereka harus setiap hari berhadapan dengan penagih hutang. Terdapat juga beberapa keluarga di desa Sukawangi yang mengalami ganguan terhadap keharmonisan keluarga karena permasalahan hutang bahkan sampai berujung pada perceraian. Pada hasil pengamatan yang dilakukan oleh penulis, hanya terdapat beberapa keluarga di desa Sukawangi yang berhasil dan sukses dalam ekonomi dengan mengelola hutang dengan baik. Mereka berhasil memanfaatkan dan mengelola hutang tersebut dengan menciptakan peluang ekonomi yang tinggi di tengah krisis pandemi Covid-19.

\footnotetext{
${ }^{32}$ Data diperoleh langsung melalui wawancara yang dilakukan kepada kedua keluarga tersebut di desa Sukawangi pada taggal 27 November, pukul 09.35 WIB.
} 
TAHKIM, Jurnal Peradaban dan Hukum Islam. Vol.4 No.l (Maret, 2021) | ISSN : 2597-7962

\section{DAFTAR PUSTAKA}

\section{Buku:}

Al-Fauzan, Syaikh Shaleh Bin Fauzan. (2013). Mulkhas Fiqih Panduang Fiqih Lengkap Jilid 2. Jakarta: Pustaka Ibnu Kasir.

Antony, Japri. (2012). Konsep Perencanaan Keuangan Keuangan Keluarga. Dokumen Internal Financial Planner Assosiasi Indonesia. 23 Agustus.

Ascarya. (2012). Akad dan Prodok Bank Syariah. Jakrta: Jarawali Press.

As-Subki, Ali Yusuf. (2010). Fiqh Keluarga. Jakarta: Amzah.

az-Zuhaili, Wahbah. (1998). al-Fiqh al-Islamy Wa 'Adillatuhu, Juz IV. Bairut: Dar alFikr.

Ch., Mufidah. (2008). Psikologi Keluarga Islam Berwawasan Gender. Malang: UIN Press.

Departemen Pendidikan Nasional. (2008). Kamus Besar Bahasa Indonesia (KBBI). Edisi Ke-4. Jakarta: PT Gramedia Pustaka Utama.

Djamil, Fathurrahman. (1997). Filsafat Hukum Islam. Ciputat: Logos Wacana Ilmu.

Faqih, Aunur Rahim. (2001). Bimbingan Dan Konseling dalam Islam. Yogyakarta: UII Press.

Hadi, Abu Sura'i Abdul. (1993). Bunga Bank Dalam Islam. Surabaya: al-Ikhlas.

Hasan, M. Ali. (2002). Berbagai Macam Transaksi dalam Islam. Jakarta: PT. Raja Grafindo Persada.

MS., Wahyu. (1986). Ilmu Sosial Dasar. Surabaya: Usaha Nasional.

Nawawi, Ismail. (2012). Fiqh Mualamah Klasih dan Kontemporer Hukum Perjanjian Ekonomi dan Bisnis dan Sosial. Surabaya: Ghalia Indonesia.

Nor, Dumairi, Sufandi, dkk. (2007). Ekonomi Syariah Versi Salaf. Pasuruan: Pustaka Sidogiri.

Nugroho, Heru. (2001). Uang, Retenir dan Hutang di Jawa. Yogyakarta: Pustaka Pelajar. Suhendi, Hendi. (2014). Fiqh Muamalah. Jakarta: Rajawali Press.

Syafi'i Ahmad Ibnu. (2002). Buluqhul Marom. Jakarta: Dar al-Kutub al-Islamiyah. Vrendenbregt, J. (1987). Metode dan Teknik Penelitian Masyarakat. Jakarta: Gramedia. Jurnal:

Nasution, Dito A. Darma, Erlina, dan Muda, Iskandar. (2020). Dampak Pandemi Covid19 terhadap perekonomian Indonesia. Jurnal Benefita, Vol. 5 No.2, (Juli). 212-224. 
TAHKIM, Jurnal Peradaban dan Hukum Islam. Vol.4 No.l (Maret, 2021) | ISSN : 2597-7962

Rustina, (2014). Keluarga dalam kajian Sosiologi. MUSAWA, Vol. 6, No. 2, (Desember), 287-322.

Syaparuddin, (2014). Pengelolaan Keuangan Keluarga Secara Profesional dalam Menwujudkan Keluarga Sakinah. Al-Risalah: Jurnal Hukum Keluarga Islam, Vol. 1, No. 1, (Juli). 76-91. 
TAHKII, Jurnal Peradaban dan Hukum Islam. Vol.4 No.l (Naret, 202I) | ISSN : 2597-7962 